\title{
Penerapan Metode Pembelajaran Role Playing Berbantuan Video Pembelajaran untuk Meningkatkan Pemahaman Konsep IPS pada Siswa Kelas V Sekolah Dasar
}

\author{
Sri Setik Nurhamami \\ SDN Wonokusumo VI/45 Surabaya \\ Jl. Wonosari Lor Baru No.21 Kecamatan Semampir, Surabaya \\ srisetik70@gmail.com
}

\begin{abstract}
The purpose of this study was to describe the improvement of the social studies concept of the fifth grade students of SDN Wonokusumo VI / 45 Surabaya by using the role playing method. This research was conducted using the Classroom Action Research (CAR) method with the research model design of Kemmis and Mc. Taggart. The research was conducted in 3 cycles. The research subjects were students of class V SDN Wonokusumo VI / 45, which may be 32 students. Collecting data using observation techniques, learning outcomes (understanding concepts) and documentation. The data from the observations are in the form of observations of teacher activities with role playing methods and observations of student activities in learning. The concept test of understanding the cognitive aspects of learning outcomes tests which is the final evaluation exercise of each cycle to measure the assessment of social studies learning by applying the video-assisted role playing method. The results showed that the use of the video-assisted role playing method could improve students' conceptual understanding as indicated by the acquisition of the average value and the proportion of classical submission from cycle I to cycle II. Students' understanding of the concept in the first cycle showed an average value of 62.50 with the classical classification proportion of $21.80 \%$ with the poor category. In the second cycle it increased to 70.94 with a classical proportion of $53.13 \%$ in the sufficient category. The average cycle III student scores increased 76.56 percent from classical $81.25 \%$ with very good category.
\end{abstract}

Keywords: Role Playing, Learning Videos, Concept Understanding.

\begin{abstract}
Abstrak
Tujuan penelitian ini untuk mendeskripsikan peningkatan konsep IPS siswa kelas V SDN Wonokusumo VI/45 Surabaya dengan menggunakan metode bermain peran. Penelitian ini dilakukan dengan menggunakan metode Penelitian Tindakan Kelas (PTK) dengan desain model penelitian Kemmis dan Mc. Taggart. Penelitian dilaksanakan dalam 3 siklus. Subjek penelitiannya adalah siswa kelas V SDN Wonokusumo VI/45 yang berjumlah 32 siswa. Pengumpulan data menggunakan teknik observasi, hasil belajar (pemahaman konsep) dan dokumentasi. Data hasil observasi berupa observasi aktivitas guru dengan metode role playing dan observasi aktivitas siswa dalam pembelajaran. Tes konsep pemahaman merupakan tes hasil belajar aspek kognitif yang terdiri dari evaluasi akhir setiap siklus untuk mengukur keberhasilan pembelajaran IPS dengan menerapkan metode bermain peran berbantuan video. Hasil penelitian menunjukkan bahwa penggunaan metode bermain peran berbantuan video dapat meningkatkan pemahaman konsep siswa yang ditunjukkan dengan perolehan nilai rata-rata dan persentase penyerahan klasikal dari siklus I ke siklus II. Pemahaman konsep siswa pada siklus I menunjukkan nilai rata-rata 62,50 dengan persentase pengklasifikasian klasikal 21,80\% dengan kategori kurang. Pada siklus II meningkat menjadi 70,94 dengan persentase klasikal 53,13\% dengan kategori cukup. Rata-rata siklus III nilai siswa meningkat 76,56 persen dari ke klasikal $81,25 \%$ dengan kategori sangat baik.
\end{abstract}

Kata kunci: Role Playing, Video Pembelajaran, Pemahaman Konsep

Copyright (c) 2020 Sri Setik Nurhamami

$\triangle$ Corresponding author: Sri Setik Nurhamami

Email Address: srisetik70@gmail.com (Jl. Wonosari Lor Baru No.21 Kecamatan Semampir, Surabaya)

Received 28 Januari 2020, Accepted 30 Desember 2020, Published 30 Desember 2020

\section{PENDAHULUAN}

Ilmu Pendidikan sosial di sekolah dasar diharapkan dapat memberikan pengetahuan dan 
pemahaman kepada siswa dalam mempersiapkan dunia sosial yang nyata dan objektif serta menjadikan mereka warga negara yang baik. Pembelajaran ilmu-ilmu sosial di sekolah dasar harus dapat memberikan pengalaman, menanamkan konsep-konsep yang bermakna dan landasan yang kuat pada anak sebagai bekal dalam hidupnya kelak. Dengan demikian, pentingnya pembelajaran ilmu sosial sangat penting.

Fakta yang terjadi di lapangan, berdasarkan hasil pembelajaran IPA di SD khususnya SDN Wonokusumo VI/45 dalam penyampaian materi IPS masih informatif dan menuntut aspek kognitif (menghafal) didominasi Guru. dan kurang melibatkan siswa dalam proses belajar mengajar. Hal tersebut membuat siswa malas memahami informasi dan konsep baik yang ada di buku maupun yang disampaikan oleh guru, mata pelajaran ilmu sosial dianggap mata pelajaran yang sulit, banyak hafalan membosankan. Siswa kurang berani menyampaikan pendapatnya di depan kelas sehingga siswa kurang mampu menggali kemampuan berkomunikasi secara maksimal. Membuat siswa menjadi pasif dalam belajar. Antusiasme siswa dalam belajar juga rendah. Hal ini dibuktikan dengan hasil ulangan siswa pada mata pelajaran IPS, hanya 6 siswa yang mampu mencapai batas kriteria penyerahan maksimal. Nilai rata-rata hasil belajar sosial adalah 62 , jauh dibawah kriteria penyampaian maksimal yaitu 73. Hasil belajar yang rendah disebabkan kurangnya pemahaman konsep materi siswa akibat pembelajaran yang kurang bermakna.

Salah satu alternatif metode pembelajaran yang dapat digunakan untuk meningkatkan kebermaknaan pembelajaran adalah metode bermain peran berbantuan video. Video dalam pembelajaran ini berfungsi sebagai media pembelajaran yang membantu siswa dalam memahami situasi, membantu dalam membentuk dan mengarahkan peran (Huda, 2013, hal 119). Metode bermain peran sering juga disebut dengan metode Sosiodrama (Suhanadji, 2003, hal 178). Menurut Hamalik (2004, p. 214), menjelaskan bahwa metode role playing merupakan metode pembelajaran dalam proses yang dilakukan dengan memberikan peran tertentu kepada peserta didik untuk didramatisasi dalam sebuah pentas. Metode pembelajaran bermain dengan cara siswa berperan serta melibatkan unsur bahagia khususnya bagi siswa sekolah dasar yang masih dalam masa permainan dan operasional konkrit. Keseruan disini berarti bangkitnya minat siswa sehingga ada keterlibatan penuh dan terciptanya materi yang dipelajari. Melalui pembelajaran, metode memainkan peran materi yang dipelajari akan efektif dan tahan lama dalam ingatan karena siswa bermain secara langsung, menggali materi pelajaran berdasarkan peran yang dimainkan (Suprijono, 2016, h. 84). Dengan metode pembelajaran role playing siswa dapat mendeskripsikan pemahaman (konsep) dalam bentuk praktek dan contoh yang menyenangkan.

Berdasarkan permasalahan tersebut, maka tujuan dari penelitian ini adalah sebagai berikut: (1) Mendeskripsikan aktivitas siswa saat pembelajaran bermain peran berbantuan video di kelas V SDN Wonokusumo VI/45 Surabaya, (2) Mendeskripsikan aktivitas guru pada saat pembelajaran memainkan peran berbantuan video pada IPS kelas V di SDN Wonokusumo VI/45 Surabaya, dan (3) mendeskripsikan pemahaman konsep siswa setelah pembelajaran Pembelajaran role-playing 
berbantuan video pada mata pelajaran IPS Kelas V SDN Wonokusumo VI/45 Surabaya.

Dalam penelitian ini, peneliti mempresentasikan beberapa review dari perpustakaan penelitian yang relevan antara lain. Pertama, penelitian Dedi Rizkia Saputra (2015). Penerapan metode RolePlaying untuk meningkatkan hasil IPS pada siswa kelas V SDN 2 Kecemen Manisrenggo Klaten. Hasil penelitian menunjukkan metode bermain peran dapat meningkatkan aktivitas dan hasil belajar IPS siswa kelas II, penelitian Rika Evalia Ariyanti (2010). Aplikasi role-playing untuk meningkatkan pemahaman teks cerita rakyat pada pembelajaran bahasa Indonesia siswa kelas V SD Negeri Tegalweru Kabupaten Malang. Hasil penelitian menunjukkan peningkatan pemahaman siswa terhadap cerita rakyat melalui metode bermain peran.

Perbedaan penelitian diatas dengan penelitian yang akan peneliti lakukan terletak pada lokasi penelitian, subjek penelitian, materi, dan media yang digunakan. Dalam penelitian lokasi penelitian ini adalah Sekolah Dasar Negeri Wonokusumo VI/45 Surabaya, subjek penelitiannya adalah siswa kelas V sebanyak 32 siswa. Subjek yang digunakan dalam penelitian ini adalah ilmu sosial dengan materi acara nasional tentang proklamasi kemerdekaan, sedangkan media yang digunakan dalam penelitian ini adalah video proklamasi kemerdekaan.

Bidang studi yang ingin diteliti dalam penelitian ini adalah tentang aktivitas dan pemahaman konsep siswa dilihat dari hasil belajar siswa pada aspek kognitif selama pembelajaran ilmu sosial dengan peran bermain peran berbantuan video. Melalui penerapan metode bermain peran video berbantuan diharapkan dapat meningkatkan aktivitas dan pemahaman konsep ilmu sosial siswa kelas V SDN Wonokusumo VI/45 Surabaya.

\section{METODE}

Metode penelitian yang digunakan adalah penelitian tindakan kelas, suatu bentuk penelitian tindakan yang diterapkan pada penggunaan metode bermain peran berbantuan video dalam pembelajaran di kelas. Hal ini dikarenakan penelitian tindakan kelas mampu menawarkan pendekatan dan prosedur yang berdampak langsung pada peningkatan dan profesionalisme guru dalam mengelola proses pembelajaran di kelas (Wardani, 2016, h. 3)

Penelitian ini dilaksanakan di Sekolah Dasar Negeri Wonokusumo VI/45 Surabaya. Kelas yang digunakan dalam subjek penelitian adalah peserta didik kelas V, yaitu kelas yang terdiri dari 32 peserta didik yang terdiri dari 16 peserta didik berjenis kelamin laki-laki dan 16 peserta didik berjenis kelamin perempuan. Penelitian tindakan kelas ini menggunakan model penelitian tindakan kelas Kemmis \& McTaggart, dengan 3 siklus. Tahapan yang digunakan adalah perencanaan, tindakan, observasi (are), dan refleksi (refleksi).

Teknik pengumpulan data dalam penelitian ini adalah: observasi, tes pemahaman konsep (tes hasil belajar kognitif) dan dokumentasi. Analisis data dilakukan dengan menggunakan teknik analisis kuantitatif dengan persentase. Data Observasi meliputi observasi aktivitas guru dan observasi aktivitas 
siswa. Analisis data observasi diperoleh dengan memberikan skor pada setiap aspek yang diamati selama proses pembelajaran pada setiap siklus. Analisis data observasi aktivitas guru dan siswa menggunakan rumus sebagai berikut:

$$
P=\frac{f}{N} \times 100 \%
$$

Keterangan:

$$
\begin{aligned}
& \mathrm{P} \text { = Persentase frekuensi kemunculan suatu peristiwa } \\
& \mathrm{f} \text { = Banyaknya aktivitas guru / siswa yang muncul } \\
& \mathrm{N} \text { = Jumlah aktivitas }
\end{aligned}
$$

Hasil tes pemahaman konsep pada setiap siklus dalam pembelajaran dianalisis secara individual dan diklasifikasikan melalui hasil tes kemampuan kognitif siswa. Penentuan tingkat pembelajaran dalam pembelajaran individual diukur berdasarkan kriteria ketuntasan minimal mata pelajaran IPS $\geq$ 73. Ketuntasan pembelajaran klasikal tercapai jika $\geq 80 \%$ jumlah seluruh siswa di kelas tuntas. Untuk menentukan nilai tes pemahaman konsep siswa menggunakan persamaan:

$$
\text { Value }=\frac{\text { Number of Score }}{\text { Maximum score Amount }} \times 100
$$

Setelah dilakukan perhitungan nilai pemahaman konsep dan rata-rata hasil pemahaman konsep IPS satu kelas, langkah selanjutnya adalah mencari persentase ketertarikan klasikal siswa pada proses pembelajaran. Untuk analisis pedoman belajar klasikal siswa terhadap proses pembelajaran dinyatakan dalam persentase dengan persamaan:

$$
P=\frac{\sum \text { Students who complete learning }}{\sum \text { student }} \times 100 \%
$$

Untuk memudahkan tingkat keberhasilan tersebut, maka kisaran kriteria penilaian yang digunakan untuk kegiatan guru, kegiatan siswa dan hasil pemahaman konsep siswa adalah sebagai berikut (Arikunto, 2008: 128):

Tabel 1. Kriteria Aktivitas Siswa Dan Hasil Belajar

\begin{tabular}{|l|l|}
\hline \multicolumn{1}{|c|}{ Interval } & \multicolumn{1}{c|}{ Kriteria } \\
\hline $80 \%-100 \%$ & Luar biasa \\
\hline $61 \%-80 \%$ & Baik \\
\hline $41 \%-60 \%$ & Cukup \\
\hline $21 \%-40 \%$ & Kurang \\
\hline
\end{tabular}

Indikator kinerja dalam penelitian ini didasarkan pada batasan kriteria minimal Ilmu Pengetahuan 
Sosial (KKM) yaitu 73 dan target ketuntasan minimal konsep siswa adalah 65. Indikator kinerja dikatakan tercapai dan penguasaan konsep siswa. Konsep acara nasional tentang proklamasi kemerdekaan Indonesia meningkat jika pada akhir siklus siswa diperoleh nilai $\geq 73 \mathrm{~s} / \mathrm{d} 80 \%$ dari jumlah siswa (persentase pembuktian klasik mencapai 80\%) dan siswa yang mendapatkan nilai $\geq 73$ lebih dari $75 \%$. Hasil observasi persentase aktivitas guru dan siswa mencapai $80 \%$.

\section{HASIL}

Pada bagian ini ditampilkan hasil kajian metode bermain peran berbantuan video untuk meningkatkan aktivitas dan pemahaman konsep siswa dilihat dari hasil pembelajaran aspek kognitif pada mata pelajaran IPS Peristiwa Nasional Tentang Proklamasi. kemerdekaan Indonesia. Penelitian tindakan kelas ini dilaksanakan melalui 3 siklus dengan alokasi waktu 3x35 menit per pertemuan.

Kegiatan siklus I dilaksanakan pada tanggal 6 Mei 2019, siklus II dilaksanakan pada tanggal 9 Mei 2019, siklus III dilaksanakan pada tanggal 13 Mei 2019. Pembelajaran dengan metode role playing dilaksanakan melalui sembilan tahap. Fase pertama adalah pemanasan. Pada fase ini guru mengenalkan siswa pada masalah yang mereka sadari sebagai soal belajar. Tahap kedua memilih pemain (peserta). Guru dan siswa mendiskusikan karakter setiap pemain dan menentukan siapa yang akan memainkannya dan bagaimana peran tersebut akan dimainkan. Fase ketiga mengatur panggung. Guru dan siswa membahas di mana dan bagaimana pengaturan peran akan dimainkan dan kebutuhan apa yang dibutuhkan. Fase keempat, mempersiapkan pengamat. Drama fase kelima (permainan peran dimulai). Bermain peran dilakukan berdasarkan skenario yang telah ditentukan dan pembagian peran. Fase keenam, diskusi, dan evaluasi peran. Fase ketujuh dimainkan lagi berdasarkan hasil evaluasi. Tahap kedelapan, diskusi, dan evaluasi akhir. Fase kesembilan, berbagi pengalaman dan generalisasi membuat kesimpulan. Pengamatan dilakukan selama kegiatan pembelajaran dengan data sebagai berikut:

Tabel 2. Rekapitulasi hasil kegiatan guru dan siswa

\begin{tabular}{|l|l|c|c|}
\hline No. & \multicolumn{1}{|c|}{ Siklus } & Persentase aktivitas guru & Persentase aktivitas siswa \\
\hline 1 & Siklus I & $70,90 \%$ & $67,65 \%$ \\
\hline 2 & Siklus II & $77,10 \%$ & $74,40 \%$ \\
\hline 3 & Siklus III & $84,25 \%$ & $80,90 \%$ \\
\hline
\end{tabular}

Dari observasi siklus diperoleh persentase pelaksanaan aktivitas guru sebesar 70,90\%, sehingga perlu dilanjutkan pada siklus berikutnya. Pada siklus II memperoleh persentase $77,10 \%$. Menunjukkan peningkatan sebesar 6,2\% dari aktivitas siklus I. Pada siklus III memperoleh persentase peningkatan sebesar $84,25 \%$ sebesar 7,15\%. Persentase ini sudah memenuhi indikator keberhasilan penelitian sebesar $80 \%$. Ketercapaian aktivitas siswa 67,65\% pada siklus I. Persentase tersebut belum mencapai indikator keberhasilan yang ditentukan. Hal ini dikarenakan siswa belum terbiasa dengan 
metode role playing, sehingga masih pasif. Pada siklus II persentase pencapaian aktivitas sebesar 74,40\% menunjukkan peningkatan sebesar $6,75 \%$ pada kriteria "baik". Pada siklus III menjadi 80,90\% yang masuk dalam kriteria "sangat baik" mengalami peningkatan sebesar 6,50\%.

Tes pemahaman konsep dalam penelitian ini merupakan tes hasil belajar kognitif siswa yang dilakukan dengan menyampaikan tes pada setiap akhir pembelajaran dari aktivitas siklus I sampai siklus III. Rekapitulasi hasil belajar siswa dari siklus I ke siklus III dapat dilihat pada tabel berikut.

Tabel 3. Rekapitulasi Hasil Belajar Siswa

\begin{tabular}{|l|c|c|c|}
\hline No & Siklus & Nilai rata-rata hasil belajar & Persentase klasik \\
\hline 1 & Siklus I & 62,50 & $21,80 \%$ \\
\hline 2 & Siklus II & 70,94 & $53,13 \%$ \\
\hline 3 & Siklus III & 76,56 & $81,25 \%$ \\
\hline
\end{tabular}

Dari tabel tersebut diketahui bahwa pada Sisklus I nilai rata-rata secara klasikal hanya 62,50, sebanyak 7 siswa dari 32 siswa tuntas pada persentase ketuntasan belajar 21,80\%. Siswa yang mendapat nilai $\geq 65$ baru 12 siswa 37,5\%. Hasil tersebut masih jauh dari kriteria keberhasilan yaitu $80 \%$, demikian penelitian berlanjut ke siklus II. Salah satu penyebab rendahnya kriteria prestasi adalah belum biasa digunakan siswa untuk menggunakan metode pembelajaran peran, mereka masih merasa malu dalam proses pembelajaran sehingga penguasaan konsep masih dan siswa masih kesulitan mengerjakan soal evaluasi.

Pada siklus II sebanyak 17 siswa dari 32 siswa tuntas belajar dan 28 siswa $(87,5 \%)$ nilai $\geq 65$. Nilai rata-rata hasil belajar pada siklus II adalah sebesar 70,94 dengan persentase klasikal klasifikasi $53,13 \%$. Nilai rata-rata pada siklus II ini belum mencapai kriteria ketuntasan minimal 73 dan indikator keberhasilan, namun terlihat telah terjadi peningkatan yang signifikan lebih dari $80 \%$ siswa sudah mendapatkan nilai $\geq 65$. Dalam II ini terjadi peningkatan yang signifikan. Siklus siswa sudah terbiasa dengan metode bermain peran. Karena belum memenuhi semua indikator keberhasilan yang ditentukan dalam penelitian ini maka penelitian dilanjutkan pada siklus III.

Siklus III sebanyak 26 siswa tuntas dalam pembelajaran 6 siswa belum tuntas, 32 siswa sudah diberikan nilai $\geq 65$. Rata-rata nilainya 76,56 , persentase klasifikasi kelas $81,25 \%$ dengan persentase ini berarti indikator keberhasilan sudah tercapai pada siklus III, karena telah mencapai indikator keberhasilan yang ditentukan dalam penelitian ini yaitu $\geq 80 \%$, dan siswa yang memperoleh nilai $\geq 65$ lebih dari $80 \%$. Berdasarkan hasil penelitian dan penjelasan di atas dapat dikatakan bahwa penerapan metode role playing berbantuan video dapat meningkatkan pemahaman konsep IPS siswa kelas $\mathrm{V}$ SDN Wonokusumo VI/45 Surabaya.

\section{KESIMPULAN}


Berdasarkan analisis data, hasil penelitian tentang peningkatan aktivitas dan pemahaman konsep siswa dengan menggunakan metode pembelajaran bermain peran berbantuan video di SDN Wonokusumo VI/45 maka diperoleh kesimpulan sebagai berikut: 1) Persentase Pelaksanaan aktivitas guru pada siklus I 70,90\% pada kategori "baik" meningkat menjadi $77,10 \%$ pada siklus II dan $84,25 \%$ pada siklus III dengan kategori "sangat baik", 2) aktivitas belajar siswa pada siklus I mendapat persentase $67,65 \%$ pada kategori "baik" naik menjadi 74,40\% pada siklus II kategori "baik" dan 80,90\% pada siklus III pada kategori "sangat baik", 3) Hasil belajar siswa pada siklus I diperoleh nilai rata-rata 62,50 dengan bukti kompensasi $21,80 \%$ kriteria "Siswa yang mempunyai nilai $\geq 65$ sebesar 37,5\%. Pada siklus II hasil belajar siswa memiliki nilai rata-rata 70,94 dengan persentase kompensasi $53,13 \%$ dengan kriteria "cukup", siswa yang mendapatkan nilai $\geq 65$ dari 87,50\%. Hasil belajar siswa siklus III nilai rata-rata 76,56 dengan penyerahan kriteria 81,25\% kriteria "sangat baik", siswa yang memperoleh nilai $\geq 65$ sebesar $100 \%$. 4) Metode pembelajaran memainkan peran berbantuan video merupakan salah satu metode pembelajaran yang dapat meningkatkan konsep IPS siswa kelas V.

\section{UCAPAN TERIMA KASIH}

Terimakasih kami ucapkan kepada Bapak/Ibu Kepala Sekolah dan Guru-guru di SDN Wonokusumo VI/45 Surabaya yang telah memberikan kesempatan kepada peneliti dalam melaksanakan penelitian. Terimakasih kepada siswa yang telah ikut berpartisipasi dalam melaksanakan penelitian ini.

\section{REFERENSI}

Abdul, Aziz Wahab. (2007). Metode dan model-Model mengajar ilmu pengetahuan sosial (IPS). Bandung: Alfabeta

Arikunto, Suharsimi. (2008). Dasar-dasar Evaluasi Pendidikan. Jakarta: Prestasi Pustaka

Diana Puspa, dan Ari Subekti. (2017). Peristiwa dalam Kehidupan. Buku Tematik Terpadu Kurikulum 2013. Jakarta: Kementerian Pendidikan dan Kebudayaan

Elizabeth Ann Graves (2008). Apakah Bermain Peran Merupakan Metode Pengajaran yang Efektif?. Universitas Ohio: Proyek Penelitian Master Dipresentasikan ke Fakultas Sekolah Tinggi Pendidikan

Faqih Samlawi, Bunyamin Maftuh. (2001). Konsep dasar IPS. Bandung: CV. Maulana Hamalik, Oemar. (2004). Proses belajar mengajar. Jakarta: Bumi Aksara

Huda, Miftahul. (2013). Model-model membangun dan pembelajaran (Isu-isu Metodis dan Paradigmatis). Yogyakarta: Pustaka Pelajar

Ibrahim, Muslimin. (2012). Konsep, miskonsepsi, dan cara pembelajarannya. Surabaya: Unesa University Press

Joyce, Bruce dan Weil, Marsha. (1992). Model pengajaran (edisi kedua). Englewood Cliffs, New Jersey: Prentice-Hall, Inc

Kemmis \& Mc. Taggart. (1988). Perencana Penelitian Tindakan. Victoria: Universitas Deakin. 
Penerapan Metode Pembelajaran Role Playing Berbantuan Video Pembelajaran untuk Meningkatkan Pemahaman Konsep IPS pada Siswa Kelas V Sekolah Dasar, Sri Setik Nurhamami

Nasution, S. (2005) .Berbagai proses pendekatan dalam belajar dan mengajar. Jakarta: BumiAksara

Rizkia, D. (2015). Penerapan Metode Role Playing untuk Meningkatkan Hasil Belajar IPS Pada Siswa Kelas V SD Negeri 2 Kecemen, Manisrenggo, Klaten.

Diperoleh dari http://journal.student.uny.ac.id/ojs/ojs/index.php/pgsd/article/viewFile/537/503

Suhanaji dan Sirajuddin. (2017). Pendidikan IPS (Hakikat, Konsep, dan Pembelajaran). Surabaya: Unesa University Press.

Suprijono, Agus. (2016). Model-model pembelajaran Emansipatoris. Yogyakarta: Pustaka Pelajar Suprijono, Agus. (2017). Pembelajaran kooperatif . Yogyakarta: Pustaka Pelajar

Trianto, (2007). Model-model Pembelajaran Inovatif berorientasi kontruktivistik. Prestasi Pustaka: Undang-undang Republik Indonesia Nomor 20 Tahun 2003 Tentang Sistem Pendidikan Nasional Wahab, Abdul Azis. (2007) .Metode dan Model-model Mengajar Ilmu Pengetahuan Sosial (IPS). Bandung: Alfabeta

Wardani, IGAK 2016. Penelitian Tindakan Kelas. Jakarta: Universitas Terbuka KTSP SD / MI 2011. 